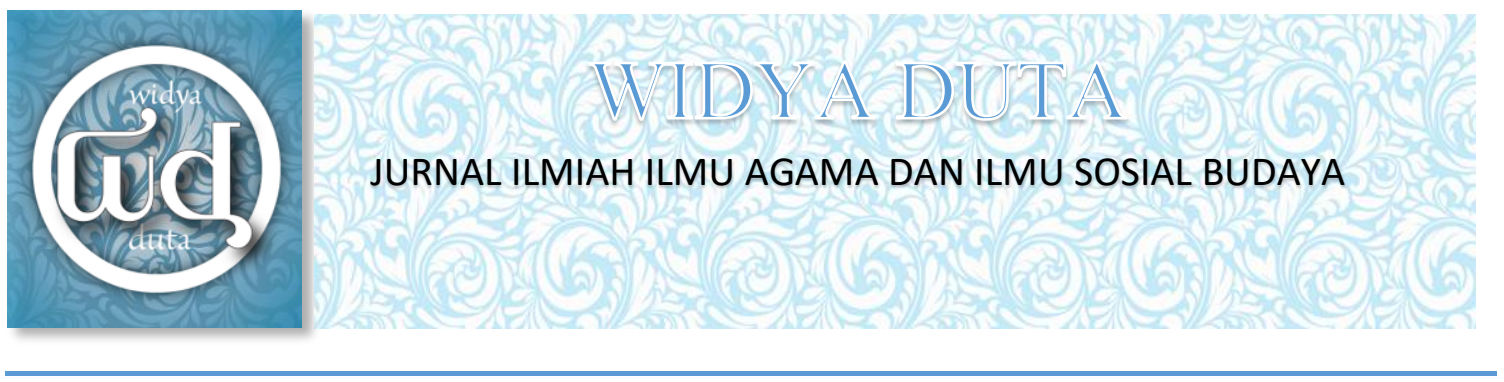

\title{
SEBUAH PURA BAGIAN DARI PERJALANAN DANGHYANG NIRARTA
}

Komang Trisna Dewi ${ }^{1}$

Universitas Hindu Negeri I Gusti Bagus Sugriwa Denpasar

Abstract

Sad Kahyangan Jagat is one of six temples. It stands majestically at the southwestern tip of Bali on a steep, high rock platform and protrudes into the sea. This temple is located in the village of Pecatu, South Kuta District, Badung Regency and this temple is easily accessible. Uluwatu Temple is divided into three parts; Utama Mandala, Madya Mandala, and Nista Mandala. At Utama Mandala there are prasada and pelinggih in the form of Meru Tumpang Tiga. In Madya Mandala there are no pelinggih. Whereas in the southern Mandala Nista called Dalem Be Pvt, there are among others prasada, where the mokshanya Danghyang Dwijendra is side by side with a monument in the form of two boats used to sail when coming to Bali. Uluwatu Temple is a well-known tourist attraction in all foreign countries, although it is already a place that is very popular with tourists does not necessarily make people forget some things that must be done by visitors (tourists) when it comes to temples. The visitors must use cloth (relapsed) and scarves so that when entering the temple area, harmony, sacred values can be interpreted by visitors. Regulations relating to the ethics of visitors who come to Uluwatu Temple must adhere to the applicable rules made by Bendesa Adat.

Keywords Temple, Tourism.

\section{PENDAHULUAN}

Pura ini merupakan salah satu dari enam buah pura yang berstatus Sad Kahyangan Jagat. la berdiri megah di ujung barat daya Pulau Bali di atas anjungan batu karang yang terjal dan tiggi serta menjorok ke laut. Pura ini berada di wilayah Desa Pecatu, Kecamatan Kuta Selatan, Kabupaten Badung

\footnotetext{
${ }^{1}$ trisnadewi78uhnsugriwa.ac.id
}

dan pura ini mudah dijangkau. Pura Luhur Uluwatu dibagi menjadi tiga bagian; Utama Mandala, Madya Mandala, dan Nista Mandala. Pada Utama Mandala terdapat prasada dan pelinggih berupa Meru Tumpang Tiga. Di Madya Mandala tidak ada pelinggih. Sedangkan pada Nista Mandala bagian selatan yang disebut Dalem Bejurit terdapat 
antara lain prasada, tempat mokshanya Danghyang Dwijendra berdampingan dengan monumen berupa dua buah perahu yang dipakai berlayar sewaktu datang ke PulauBali. Pura ini banyak dikunjungi wisatawan baik luar maupun dalam negeri. Selain itu, pura ini pernah mendapat bantuan dari Korea pada tahun 1989 sebanyak delapan puluh tujuh juta rupiah. Di sekitar lokasi pura ini juga dihuni oleh puluhan ekor kera, seperti halnya terdapat di Pura Bukit Sari, Sangeh atau Pura Pulaki. Sampai sekarang tidak banyak orang tahu sejarang perjalanan Danghyang Nirarta mencapai moksha di Pura Uluwatu, yang berkaitan dengan sejarah adanya Pura Uluwatu dan upaya pengempon Pura Uluwatu yang ada di sekitar Desa Pecatu Kecamatan Kuta Selatan Kabupaten Badung. Maka dari itu, jelaslah perjalanan Danghyang Nirarta mencapai moksha di Pura Uluwatu dengan konsep kebudayaan yang adiluhung masih tetap dijaga oleh umat Hindu khsuusnya yang menjadi pengempon Pura Uluwatu.

\section{Kerangka Teori}

Duranti (1997:2) mengatakan bahwa antropologi linguistik mengkaji ujaran dan bahasa dalam konteks antropologi. Berdasarkan pendapat Hymes tersebut, Duranti kemudian merumuskan pengertian antropologi linguistik sebagai studi mengenai bahasa sebagai sumber budaya dan mengaji wicara sebagai tindakan budaya. Duranti juga menegaskan bahwa linguistikan tropologi „tidak bersinonim " dengan studi bahasa yang dilakukan oleh ilmuwan antropologi. Meskipun difokuskan pada telaah bahasa, namun Duranti (ibid.) menempatkan antropologi linguistik sebagai bagian dari antropologi.

$$
\text { Berbeda dengan Duranti, Foley }
$$
(1997:3) menggunakan istilah linguistik antropologi. Jika Duranti (1997:1) memandang antropologi linguistik digunakan secara bervariasi dengan linguistik antropologi, maka Foley (1997:3), berpendapat lain, dan secara tegas mengatakan: "Anthropological linguistics is that subfield of linguistics..." Menurutnya, linguistik antropologi memandang dan mengkaji bahasa dari sudut pandang antropologi, budaya, dan bahasa untuk menemukan makna di balik pemakaiannya. Foley juga mengatakan bahwa linguistik antropologi adalah disiplin ilmu yang bersifat interpretatif yang lebih jauh mengupas bahasa untuk menemukan pemahaman budaya (cultural understanding).

Kuper dan Kuper (2000) menyebutkan keterkaitan bahasa dan budaya dalam tiga hal, yaitu: bahasa sebagai bagian budaya, bahasa sebagai indeks budaya, dan bahasa sebagai simbol budaya. Bahasa sebagai Bagian Budaya: Sebagian besar perilaku manusia dilingkupi oleh bahasa, sehingga bahasa menjadi bagian yang tidak terpisahkan dari budaya. Realitas upacara, nyanyian, ceritra, mantera, kutukan, doa, dan hukum adalah tindakan, kejadian, atau peristiwa bahasa. Siapapun yang akan memasuki dan memahami sebuah budaya harus menguasai bahasanya karena hanya melalui bahasa, seseorang bisa berpartisipasi dan mengalami sendiri sebuah budaya. Sejalan dengan topik dalam kajian ini yaitu bagaimana perjalanan Danghyang Dwijendra mencapai moksa di Pura Uluwatu, dari cerita tersebut dapat diketahui adanya budaya dibalik Pura Uluwatu yang saat ini dijadikan juga sebagai objek wisata di Pulau Bali. 


\section{METODE PENELITIAN}

Makalah sederhana ini menggunakan pendekatan linguistik deskriptif dan pendekatan linguistik kebudayaan. Pengumpulan data dilakukan dengan observasi lapangan (Pura Uluwatu yang ada di Desa Pecatu Kecamatan Kuta Selatan Kabupaten Badung). Pengumpulan data menggunakan metode simak catat. Metode simak catat ini langsung digunakan pada saat pengambilan data ke lapangan dengan narasumber pemangku atau pengempon pura yang ada di wilayah Desa Adat Pecatu Kecamatan Kuta Selatan Kabupaten Badung.

\section{PEMBAHASAN}

\section{Perjalanan Danghayng Nirarta Mencapai Moksha di Pura ULuwatu}

Sekitar tahun 1115-1130 Masehi di Kediri Jawa Timur memerintahlah seorang raja bernama Prabu Kamesuara. Raja ini menganut agama Hindu aliran Wisnu. Salah seorang putranya yakni Sri Wira Dalem Kesari, sekitar tahun 11135, dinobatkan sebagai raja di Pulau Bali. Ketika itu beliau berkeraton di Koripan Besakih yang terletak di kaki Gunung Agung. Raja ini juga memeluk agama Hindu sebagaimana agama yang dianut oleh ayahnya di Kediri.

Pada masa itu telah berada di Bali seorang Purohita dan sastrawan terkenal bernama Empu Kuturan. Empu Kuturan datang ke Pulau Bali sekitar tahun 1039 Masehi. Beliau menata kehidupan keagamaan di daerah ini. Saat itu agam Hindu di Bali terdiri dari berbagai aliran yakni Brahma, Wisnu, Siwa dan Budha. Konsep yang diterapkan Empu Kuturan adalah konsep Rwa Bhineda yang artinya mengkultuskan Hyang Widhi di dalam manifestasinya sebagai Sanghyang Luhur Akasa dan Sanghyang Ibu Pertiwi. Meskipun demikian, kehidupan beragama di Bali berjalan dengan baik. Di antara satu aliran dengan aliran lainnya hidup rukun dan Pulau Bali sangat tentram dan damai.

Pada saat itu Raja Sri Wira Dalam Kesari banyak membangun Wihara dan pertapaan tempat para biksu, purohita dan pandita melaksanakan yoga semadhi dan tapa. Selain itu banyak pula dibangun pura kahyangan untuk orang-orang Bali melaksanakan persembahyangan ke hadapan Hyang Widhi. Pura Kahyanga yang dibangun sebanyak 17 pura antara lain; Pura Batukaru, stana Bhatara Mahadewa, Pura Kiduling Kreteg stana untuk Bhatara Brahma, Pura Watumadeg stana Bhatara Wisnu, Pura Gelap stana Bhatara Iswara, Pura Uluwatu pesimpangan Bhatara Mahajaya sebuah Pura Penataran yang biasanya terletak di hulu desa sebagai stana Bhatara Luhur Akasa. Kemudian di hilir desa dibangun Pura Dalem yang berfungsi sebagai Kahyangan Wisesa dengan Prajapati dan setra-nya.

Konsep mengenai bentuk dan penataan pura jaman itu jelas merupakan konsep Empu Kuturan yang sampai saat ini masih dapat kita lihat di desa-desa kuno di Bali. Sedangkan di tanah di Jawa banyak pula dibangun tempat pemujaan berupa candicandi yang disebut prasada. Tempat suci ini berfungsi untuk leluhur yang telah amoring acintia (meninggal dunia). Candi-candi yang terdapat di tanah Jawa ini hampir sama bentuknya dengan candi-candi yang ada di Pulau Bali. Misalnya candi yang ada di Gunung Kawi, Tampaksiring maupun candi Loro Jonggrang di Jawa Tengah.

Demikian juga halnya adanya onggokan-onggokan batu di Pura Uluwatu di jaman dahulu yang merupakan tempat pemujaan leluhur yang telah amoring acintya. Onggokan batu yang bertumpuk itu 
telah terbungkus bearada di dalam candi yang disebut prasada yang ada sekarang. Pemugaran ini dilaksanakan sekitar tahun 1980, dipugar dalam bentuk Candi Catur Dwara bertumpang tujuh. Fungsinya, yakni sebagai stana Bhatara Puser Bumi yang berada di depan kiri Pelinggih Meru Tumpang Tinggi.

Untuk memelihara candi yang berada di Pura Uluwatu, Raja Sri Wira Dalem Kesari mengambil tanah-tanah bebukitan yang terbentang sangat luas di sekitar Uluwatu. Tanah itu merupakan tanah "Bukti Wetbet Bali Mula" untuk memelihara candi tersebut baik demi kepentingan spiritual amupun material. Dengan demikian orang-orang yang memperoleh "pecatu" menamakan dirinya "Wong Pecatu". Lambat laun karena adanya para pendatang baru yang menetap di daerah itu terbentuklah sebuah desa adat yang disebut Desa Adat Pecatu.

Sekitar tahun 1460-1550 Masehi, saat pemerintahan Dalem Batur Enggong yang berkeraton di Gelgel Klungkung. Pulau Bali memiliki alam yang sangat subur. Berkat kepemimpinan Dalem yang arif dan bijaksana, rakyat hidup rukun dan damai. Hampir tidak pernah terjadi permasalahan atau kasus yang berarti di kalangan orangorang Bali. Maka sekitar tahun 1489 Masehi datanglah ke Pulau Bali seorag purohita, sastrawan dan rohaniawan bernama Danghyang Dwijendra. Danghyang Dwijendra adala seorang pendeta Hindu, kelahiran Kediri, Jawa Timur.

Danghyang Dwijendra pada waktu walaka bernama Danghyang Nirarta. Beliau menikahi seorang putri di Daha Jawa Timur. Di tempat itu pila berliau berguru dan didiksa oleh mertuanya. Dnghyang Nirarta dianugerahi bhiseka kawikon dengan nama Danghyang Dwijendra.
Setelah didiksa, Danghyang Dwijendra diberi tugas melaksanakan dharmayatra sebagai salah satu syarat kawikon. Dharmayatra ini harus dilaksanakan di Pulau Bali, dengan tambahan tugas yang sangat berat dari mertuanya yaitu menata kehidupan adat dan agama khususnya di Pulau Bali. Bila dianggap dharmayatra itu dapat diteruskan ke Pulau Sasak dan Sumbawa. Konsep penataan kahyangan di Bali adalah konsep Tri Purusa dan TriKahyangan. Sedangkan konsep pendahulunya yakni Rwa Bhineda. Konsep Tri Purusa atau Tri Kayangan adalah penjabaran yang nyata dari sifat dan kekuatan Hyang Widhi, yakni Brahma, Wisnu dan Siwa. Tri Kahyangan ini dipisah-pisahkan stananya dalam bentuk Kahyangan Desa, Puseh dan Dalem Wisesa dengan Prajapati dan setra nya. Hal ini jelas dapat dilihat pada desa "Apanasa" yang telah berintegritas dari sistem pra Majapahit waktu Empu Kuturan menata Pulau Bali dengan sistem baru penataan Danghyang Dwijendra yang mendukung sistem jaman Majapahit.

Danghyang Dwijendra datang ke Pulau Bali kali pertama menginjakkan kakinya di pinggiran pantai barat daya daerh Jembrana (asal Jimbar + Wana), untuk sejenak beristirahat sebelum melanjutkan perjalanan dahrmayatranya. Di tempat inilah Danghyang Dwijendra meninggalkan pemutik (ada juga disebut pengutik) dengan tangkai (pati) kayu ancak. Sampai sekarang daun kayu ancak dipergunakan sebagai kelengkapan banten di Bali. Sebagai peringatan dan penghormatan terhadap beliau, dibangunlah sebuah pura yang diberi nama Purancak.

Setelah mengadakan dharma yatranya ke pulau Sasak dan Sumbawa, Danghyang Dwijendra menuju barat daya ujung selatan Pulau Bali, yaitu pada daerah gersang, penuh batu yang disebut daerah 
berbukitan. Oleh karena sangat gersang dan sulit mencari sumber air, maka tak cocok untuk pertanian.

Setelah beberapa saat di sana, merasa mendapat panggilan dari Hyang Pencipta untuk segera kembali amoring acintya para moksha. Di tempat lain inilah Ida Pedanda Sakti Wawu Rauh teringat (icang eling) dengan semaya (janji) dirinya untuk kembali ke asalnya. Itulah sebabnya tempat kejadian ini disebut "Cangeling"., dan lambat laun menjadi Cengiling sampai sekarang.

Oleh karena itulah Ida pedanda Sakti Wawu Rauh ngulati (mencari) tempat yang dianggap aman dan tepat untuk melakukan parama moksha. Oleh karena dianggap tidak memenuhi syarat, beliau berpindah lagi ke lokasi lain. Di tempat ini, kemudian dibagun sebuah pura yang diberi nama Pura Kulat. Nama itu berasal dari kata Ngulati. Pura itu berlokasi di Desa Pecatu Kecamatan Kuta Selatan Kabupaten Badung.

Ida Pedanda Sakti Wawu Rauh belum juga menemukan tempat yang dianggap tepat untuk parama mokhsa. Beliau kemudian tiba di sebuah tempat yang penuh batu-batu besar. Tidak ada seorang manusia pun di sini. Juga tidak terdengar suara burung. Beliau hanya merasa sendirian. Di tempat ini, lalu didirikan sebuah pura yang diberi nama Pura Batu Diyi. Pura ini diempon oleh sebuah keluarga dari Banjar Tengah, Desa Adat Pecatu, serta keluarga besar dari Banjar Denpasar.

Di tempat ini juga Danghyang Dwijendra merasa kurang aman untuk parama moksha. Dengan perjalanan yang cukup melelahkan menahan lapar dan dahaga, akhirnya beliau tiba di daerah bebukitan yang selalu mendapat sinar matahari terik. Untuk memayungi diri, beliau mengambil sebidang daun kumbang dan berusaha mendapatkan sumber air minum. Setelah berkeliling tidak menemukan sumber air minum, akhirnya Danghyang Dwijendra menancapkan tongkatnya. Maka keluarlah air amertha. Di tempat ini lalu didirikan sebuah pura yang disebut dengan Pura Payung dengan sumber mata air yang dipergunakan sarana tirta sampai sekarang.

Ida Pedanda Saktu Wawu Rauh kemudian beranjak lagi ke lokasi lain, untuk menghibur diri sebelum melaksanakan detikdetik akhir yang mencekam itu. Ditempat ini lalu didirikan sebuah pura yang bernama Pura Selonding yang berlokasi di Banjar Kangin Desa Adat Pecatu. Setelah puas menghibur diri, Danghyang Dwijendra merasa Lelah. Maka beliau mencari tempat untau beristirahat. Saking lelahnya sampai-sampai beliau ketiduran. Di tempat ini lalu didirikan sebuah pura yang diberi nama Pura Parerepan. Yang berlokasi di Desa Adat Pecatu.

Mendekati detik-detik akhir untuk parama moksa, Danghyang Dwijendra menyucikan diri dan mulat sarira terlebih dahulu. Di tempat ini sampai sekarang berdirilah sebuah pura yang disebu Pura Pengeleburan yang berlokasi di Banjar Kauh Desa Adat Pecatu. Setelah menyucikan diri, beliau melanjutkan perjalanannya menuju lokasi ujung barat daya Pulau Bali. Tempat ini terdiri atas batu-batu tebing. Apabila diperhatikan dari bawah permukaan laut, kelihatan saling bertindih, berbentuk kepala bertengger diatas batu-batu tebing itu, dengan ketinggian 50-100 meter dari permukaan laut. Dengan demikian disebut Ulu watu. Ulu = kepala dan Watu = batu. Tegasnya batu yang berkepala batu.

Sebelum Danghyang Dwijendra parama moksa, beliau memanggil juragan perahu yang pernah membawanya dari 
Sumbawa ke Pulau Bali. Juragan perahu itu bernama Ki Pacek Nambangan Perahu. Sang Pandita minta tolong agar juragan perahu membawa pakaian dan juga tongkatnya kepada istri beliau yang keempat dipasraman Griya Sakti Mas di Banjar Pule, Desa Mas, Ubud, Gianyar. Pakaian itu berupa jubah sutra berwana hijau muda serta tongkat kayu. Benda itu sampai sekarang masih tersimpan baik di salah satu Griya Brahmana Wangsa di Desa Mas. Setelah Ki Pacek Nambangan Perahu berangkat menuju pasraman Danghyang Dwijendra di Mas., Ida Pedanda Sakti Wawu Rauh segera menuju sebuah batu beser di sebelah timur onggokan batu-batu bekas candi penginggalan Kerajaan Sri Wira Dalem Kesari. Di atas batu itulah, Ida Pedanda Sakti Wawu Rauh beryoga mengranasika, laksana keris lepas saking urangka, hilang tanpa bekas, amoring acintia parama moksa. Sekitar tahun 1672 Isaka 1549 Kerajaan Mengwiraja, dengan rajanya yang bergelar I Gusti Agung Putu yang mabhiseka Ida Cokorde Sakti Blambangan mempersunting seorang istri bernama I Gusti Agung Ayu Panji, putri dari raja Buleleng yang bergelar I Gusti Agung Panji Sakti. Dalam rangkaian perkawinannya itu I Gusti Agung Panji Sakti memberikan hadiah berupa "tetatadan gumi" yang merupakan daerah kekuasaan kerajaan Buleleng. Tatadan itu berupa kekuasaan wilayah dari Jimbaran sampai ke ujung Selatan Pulau Bali dan daerah Blambangan Jawa Timur. Pada saat pemerintahan Raja Mengwi Ida Cokorde Sakti Blambangan menguasai tanah Jimbaran sampai Ulu Watu, terlihatlah di sekitar Ulu Watu berupa teja gumulung (sinar bulat) setiap sore selama beberapa hari. Peristiwa adanya teja gumulung itu dicek kebenarannya dengan mengutus seorang abdi puri Mengwiraja. Ternyat sinar yang memancar setiap sore itu adalah berupa onggokan batu yang membeku di sebelah barat onggokan batu bekas peninggalan Raja Sri Wira Dalem Kesari zaman dahulu.

Raja Mengwi, setelah mempertimbangkan matang-matang lalu membuat candi yang disebut prasada di onggokan batu itu. Sayang, candi itu tidak bertahan lama, karena hancur akibat goyangan gempa. Namun Raja tidak putus asa. Sesudah gempa dibangunlah Palinggih Meru Tumpang Tiga dengan menstanakan Ida Pedanda Sakti Wawu Rauh. Hal inipun tidak bertahan lama pula. Palinggih inikedapatan sudah jadi abu terbakar beberapa lama kemudian. Oleh karena situasi sudah berubah, maka oleh masyarakat Desa Adat Pecatu pada bekas palinggih itu dibangun kembali tempat pemujaan berupa candi. Ternyata juga tidak bertahan lama karena goncangan gempa. Masyarakat Desa Adat Pecatu kembali membangun Palinggih Meru Tungpang Tiga. Aneh, palinggih ini juga mengalami kebakaran. Namun umat tak menyerah. Setelah peristiwa kebakarn kedua kalinya itu, masyarakat kembali membangun Palinggih Meru Tungpang Tiga. Palinggih stana Danghyang Dwijendra itu masi tegak sampai sekarang.

Sedangkan diatas batu dimana Danghyang Dwijendra parama moksha dibuatlah sebuah patung seorang pandita, sebagai wujud Danghyang Dwijendra semasih hidup. Tempat ini disebut "Dalem Bejurit" (artinya pertemuan batin Danghyang Dwijendra antara mempertahankan hidup atau mati).

Di samping sebelah kanan arca (simbolis Danghyang Dwijendra), terdapat sebuah batu besar sebagai simbol buah labu besar (buah waluh pahit) Labu itu dijadikan "perahu" oleh Danghyang Dwijendra sewaktu WIDYA DUTA | VOL. 16, NO. 1 |2021 
menyebrangi lautan Selat Bali, berangkat dari Blambangan Jawa Timur dan kemudian turun berlabuh di Purancak. Sedangkan di sebelah kiri arca itu terdapat pula sebuah batu besar sebagai simbol dari sampan bocor (jukung bocor). Sampan itu bocor karena tak kuat menampung putra-putri Danghyang Dwijendra yang bersama-sama diajak ke Bali, Pada lokasi di jeroan pura terdapat:

a. Palinggih Meru Tumpang Tiga, stana Danghyang Dwijendra alias Ida Pedanda Sakti WawuRawuh.

b. Candi alias prasada, stana Ida Bahatara PuserBumi.

c. Dua buah tajuk kecil, stana Anglurah (Bhuta Raja dan KalaRaja)

d. Palinggih Dalem Bejurit (Tepas dan Arca), stana Danghyang Dwijendra alias Ida Pedanda Sakti WawuRawuh.

e. Meru Tumpang Kalih, stana Luhur Akasa dan Pratiwi (RwaBhineda).

f. Dua buah tajuk kecil, stana Anglurah (kala danDrokala).

g. Dua buah tajuk kecil ( di depan candi bentar), stana Anglurah ( Kala dan Maha Kala).

h. Bale gedong/kulkul, stana Bhataralswara.

i. Bale pasiakrana, tempat Dharmatulla.

j. Bale Parantenan, tempat dapur suci waktu karya.

k. Wantilan besar, tempat umat berteduh/rapat, danlain-lain.

\section{Pura Uluwatu Sebagai Objek Wisata.}

Pura Uluwatu memiliki daya tarik yang luar biasa bagi wisatawan domestik dan wisatawan mancanegara. Wisatawan yang berkunjung ke Pura Uluwatu selain untuk melihat dan mengamati bangunan pura dengan arsitektur yang megah juga untuk menikmati tarian Kecak yang disuguhkan setiap sore hari. Tarian Kecak ini dipertunjukkan untuk para wisatan domestik dan wisatawan mancanegara dalam kaitannya untuk memperoleh masukan sumber dana. Sumber dana ini akan digunakan oleh Bendesa Adat untuk pengelolaan saran dan prasaran di lingkungan pura. Pengunjung akan disuguhkan oleh pertunjukkan tarian Ramayana (Kecak Dance). Tarian ini mengisahkan Ramayana dan Dewi Sita. Tarian ini dapat dinikmati oleh para pengunjung dengan terlebih dahulu membeli tiket masuk.

Pura Uluwatu dijadikan objek wisata yang terkenal di seluruh mancanegara, walaupun sudah merupakan tempat yang sangat digemari oleh para wisatawan tidak lantas masyarakat melupakan beberapa hal yang harus dilakukan oleh pengunjung (para wisatawan) ketika datang ke pura. Para pengunjung harus menggunakan kain (kamben) dan selendang agar ketika memasuki areal pura, keharmonisan, nilai sakral dapat dimaknai oleh pengunjung. Peraturan yang berkaitan etika pengunjung yang datang ke Pura Uluwatu hars mematuhi aturan yang berlaku yang telah dibuat oleh Bendesa Adat.

Tradisi Untuk Menjaga Kebudayaan Yang Adiluhung Dari Masyarakat Pengempon Pura Uluwatu.

Piodalan di Pura Uluwatu yang jatuhnya setiap enam bulan sekali tepatnya pada Anggara Kasih Medangsia. Mayarakat Desa Pecatu (Pengempon) melaksanakan kegiatan mekiis atau melasti yang berwal dari Pura Pererepan sampai tujuannya yaitu di Pura Uluwatu. Pretima yang melambangkan Betara Sakti Wawu Rauh diiringi oleh gamelan dan beberapa ritual keagamaan 
(dewa yadnya) disguhkan untuk memuja kemahakuasaan Ida Sang Hyang Widhi Wasa sebagai wujudnya Betara. Masyarakat secara serempak melakukan kegiatan mekiis yang dimulai dari Pura Pererepan hingga sampai di Pura Uluwatu. Pretima akan kembali diletakkan atau dibawa lagi ke Pura Pererepan pada malam harinya setelah runtutan ritual upacara dewa yadnya selesai dilaksankan di Pura Uluwatu. Masyarakat dapat melakukan pemujaan atau peersembahyangan selama kurang lebih 4 hari. Tradisi mekiis juga akan dilengkapi dengan acara mekiis lengkap dengan pertunjukkan Barong yang disuguhkan oleh masyarakat Desa Adat Jimbaran. Masyarakat Desa Adat Jimbaran harus menampilkan tarian Barong demi menetralisir hal-hal negatif.

Tradisi Pertunjukan Barong lengkap dengan iringan gamelan dan pemedek yang melaksanakan acara mekiis akan memperlengkap betapa sakralnya pemujaan yang dilakukan masyarakat terhadap Ida Betara Wawu Rauh. Tradisi yang tidak kalah pentingnya lagi yakni upacara myineb yaitu upacar berakirnya kegiatan dewa yadnya dengan tanda dilaksanaknnya upacara medateng datengan. Upacara medateng datengan ini merupakan upacara mendatangkan para wujud dewa yang berstana di lingkungan wilayah Desa Adat Pecatu.

\section{PENUTUP}

Perjalanan Dyanghyang Nirarta mencapai moksha di Pura Uluwatu yang berada di Desa Pecatu Kecamatan Kuta Selatan Kabupaten Badung, hingga sampai sekarang di "empon" oleh masyarakat sekitar dengan melestarikan beberapa tradisi atau ritual untuk menyembah Danghayang Nirarta. Danghyang Dwijendra yang disebut juga Ida Pedanda Sakti Wawu Rawuh parama moksha atau disebut "Ngaluhur", Ulu Watu menjadi Pura "LUHUR ULUWATU"

\section{UCAPAN TERIMAKASIH}

Penelitian ini dilakukan secara mandiri, peneliti sangat berterima kasih kepada IHDN Denpasar yang telah memberikan ijin kepada peneliti untuk melakukan penelitian ini.

\section{DAFTAR PUSTAKA}

Duranti, A. 1997. Linguistic Anthropology. Cambridge: Cambridge University Press.

Foley, W. A. 1997. Anthropological Linguistics: An Introduction.Oxford: Blackwell Publishers.

Kuper, A. dan Kuper, J. (ed). 2000. Ensiklopedi Ilmu-ilmu Sosial (terjemahan oleh Haris Munandar, dari judul asli: The Social Science Encyclopedia). Jakarta: PT Raja GrafindoPersada.

Bali Post Tim Redaksi. 2006. Mengenal Pura. Denpasar: Pustaka Bali Pos 